\title{
PENINGKATKAN PRESTASI BELAJAR DENGAN METODE DISKUSI BERBANTU MEDIA VISUAL
}

\author{
Sukarni \\ SDN Wiladeg Karangmojo Gunungkidul \\ E-mail : egisukarni@gmail.com
}

\begin{abstract}
Abstrak
Penelitian ini bertujuan untuk meningkatkan prestasi belajar pada siswa khususnya kelas II SD Negeri Wiladeg, Wiladeg,Karangmojo,Gunungkidul dengan menggunakan metode diskusi berbantuan media audio visual.Penelitian ini dilakukan di SD Negeri Wiladeg pada tahun pelajaran 2019/2020. Penelitian ini adalah penelitian tindakan kelas dengan beberapa tahap penelitian yaitu perencanaan, pelaksanaan, pengamatan, dan refleksi. Subjek penelitian ini adalah siswa kelas II SD Negeri Wiladeg yang berjumlah 20 siswa dan objek penelitian ini adalah penerapan metode diskusi berbantuan media audio visual. Teknik pengumpulan data yang digunakan dalam penelitian ini adalah observasi, tes, dan dokumentasi. Data dianalisis secara deskriptif kuantitatif. Indikator keberhasilan penelitian ini ditandai dengan meningkatnya prestasi belajar siswa yaitu minimal $80 \%$ dari jumlah siswa di kelas mendapat nilai mencapai $\mathrm{KKM} \geq 75$.Berdasarkan hasil penelitian tindakan kelas dengan penerapan metode diskusi berbantuan media audio visual dapat disimpulkan bahwa : (1) prestasi belajar siswa meningkat dari rata-rata prestasi belajar sebelum tindakan sebesar 67,07 dengan persentase ketuntasan $44 \%$ menjadi 73,09 dengan persentase ketuntasan $73 \%$ pada siklus I dan rata-rata 83,79 dengan persentase ketuntasan $100 \%$ pada siklus II; (2) pembelajaran pada siklus I dan siklus II secara umum sudah terlaksana dengan baik sesuai dengan RPP.
\end{abstract}

Kata kunci : Metode Diskusi, Media Audio Visual, Prestasi Belajar

\section{PENDAHULUAN}

Berdasarkan hasil observasi pembelajaran di SD N Wiladeg pada bulan Januari 2020 di kelas II belum optimal. Hal ini dapat dilihat dari pemilihan metode yang digunakan guru masih menggunakan metode ceramah, yang kemudian dilanjutkan dengan mencatat materi sesuai dengan yang diberikan guru. Teknik pembelajaran dengan metode ceramah ini mengakibatkan kurangnya keaktifan siswa dalam proses pembelajaran. Pembelajaran lebih banyak dilaksanakan secara klasikal, tanpa alat bantu atau peraga. Media pembelajaran yang digunakan pun masih sangat sederhana, sehingga siswa pasif dalam 
mengikuti pelajaran, sering merasa jenuh, dan melakukan hal-hal di luar aktivitas belajarnya. Dengan sistem pembelajaran seperti ini siswa merasa kesulitan dalam menerima materi pelajaran, karena siswa hanya tahu sebatas apa yang ditulis dalam buku pelajaran (abstrak) dan pembelajaran tersebut tidak berkesan bagi siswa. Hal ini juga sangat memungkinkan pelajaran akan cepat dilupakan oleh siswa. Oleh karena itu, sistem pembelajaran perlu dilakukan perbaikan

Metode diskusi merupakan metode yang dapat membuat siswa aktif karena siswa memperoleh kesempatan berbicara atau berdialog untuk bertukar pikiran dan informasi tentang suatu topik atau masalah dan mencari fakta atau pembuktian yang dapat digunakan bagi pemecahan masalah. Metode diskusi adalah metode mengajar yang erat hubungannya dengan memecahkan masalah atau problem solving (Muhibbin Syah,2000).. Metode diskusi adalah cara penyajian pelajaran di mana siswa dihadapkan kepada suatu masalah yang bisa berupa pernyataan atau pertanyaan yang bersifat probematis untuk dibahas dan dipecahkan bersama (Djamarah dan Aswan: 2006)

Menurut Sri Anifah, (2010:55) media audio visual adalah media yang menunjukkan unsur auditif (pendengaran) maupun visual (penglihatan).Menurut WS Winkel prestasi belajar adalah keberhasilan usaha yang dicapai seseorang setelah memperoleh pengalaman belajar atau mempelajari sesuatu7 .Dalam Kamus Besar Bahasa Indonesia adalah: penguasaan pengetahuan atau keterampilan yang dikembangkan oleh mata pelajaran, lazimnya ditunjukan dengan nilai tes atau angka nilai yang diberikan oleh guru. Menurut Djalal "prestasi belajar siswa adalah gambaran kemampuan siswa yang diperoleh dari hasil penilaian proses belajar siswa dalam mencapai tujuan pengajaran"8 Hamalik berpendapat bahwa prestasi belajar adalah perubahan sikap dan tingkah laku setelah menerima pelajaran atau setelah mempelajari sesuatu.9 Benyamin S. Bloom, prestasi belajar merupakan hasil perubahan perilaku yang meliputi tiga ranah kognitif terdiri atas: pengetahuan, pemahaman, aplikasi, analisis, sintesis, dan evaluasi.10 Saifudin Azwar mengatakan prestasi belajar merupakan dapat dioperasionalkan dalam bentuk indikator-indikator berupa nilai raport, indeks prestasi studi, angka kelulusan dan predikat keberhasilan. 
Menurut Drs. H. Abu Ahmadi menjelaskan Pengertian Prestasi Belajar sebagai berikut: Secara teori bila sesuatu kegiatan dapat memuaskan suatu kebutuhan, maka ada kecenderungan besar untuk mengulanginya. Sumber penguat belajar dapat secara ekstrinsik (nilai, pengakuan, penghargaan) dan dapat secara ekstrinsik (kegairahan untuk menyelidiki, mengartikan situasi).Disamping itu siswa memerlukan/ dan harus menerima umpan balik secara langsung derajat sukses pelaksanaan tugas (nilai raport/nilai test)

\section{METODE}

Penelitian dilakukan di SDN Wiladeg wilayah Koprdinator Wilayah Kecamatan Karangmojo Kabupaten Gunungkidul Daerah Istimewa Yogyakarta. SDN Wiladeg terletak di Km 6 Jln Wonosari - Karangmojo. Ruang lingkup penelitian ini meliputi keefektifan penngunaan metode diskusi berbantu media audio visual dalam meningkatkan pemahaman anak, ketercapaian KKM, dan juga respon peserta didik terhadap pembelajaran menggunakan model pembelajaran menggunakan metode ini.Subyek dari penelitian adalah peserta didik Kelas II SDN Wiladeg wilayah Koordinator Wilayah Kecamatan Karangmojo Kabupaten Gunungkidul Daerah Istimewa Yogyakarta.Desain dari penelitian yang ditetapkan adalah penelitian tindakan kelas (classroom action research). Secara rinci tahapan-tahapan dalam rancangan penelitian tindakan kelas adalah sebagai berikut: 1).Perencanaan (Planning) Arikunto (2012: 118) mengatakan kegiatan planning antara lain (1) identifikasi masalah, (2) perumusan masalah dan analisis penyebab masalah, dan (pengembangan intervensi adalah memperbaiki PBM pada materi menentukan pasangan bilangan dengan hasil kali tertentu dengan model potongan kertas warna.2).Pelaksanaan Tindakan /Acting dan Pemantauan/ Observasi Action (intervensi) dilaksanakan untuk memperbaiki masalah (Arikunto, 2012:126). Kegiatan yang dilakukan dalam pelaksanaan tindakan adalah guru kelas II sebagai peneliti melaksanakan proses pembelajaran dengan menggunakan metode diskusi dengan sebelum diskusi siswa ditunjukkan tayangan berupa vidio oudio visual untuk bahan diskusi.Kegiatan pemantauan atau observasi di dalam penelitian ini 
dilaksanakan secara bersama-sama dengan kegiatan pelaksanaan tindakan. Kegiatan observasi dilaksanakan dengan cara mengobservasi guru yang sedang mengajar dan murid yang sedang belajar menggunakan pedoman pemantauan proses belajar mengajar yang telah disusun. Observasi dilakukan oleh dua orang observer yaitu teman sejawat dan kepala sekolah.Reflection adalah kegiatan mengulas secara kritis (reflectiction) tentang perubahan yang terjadi (a) pada siswa, (b) suasana kelas, dan (c) guru (Arikunto, 2012: 133). Refleksi pada penelitian ini dilakukan untuk mengkaji apakah tindakan yang dilakukan sudah berhasil atau belum. Berdasarkan hasil refleksi, maka tindakan berikutnya dapat ditentukan.

Teknik yang digunakan adalah teknik tes dan non tes. Tes digunakan untuk mendapatkan nilai hasil belajar peserta didik terhadap materi yang disampaikan. Tes yang digunakan dalam tes sebelum tindakan untuk menjajaki kemampuan awal peserta didik, dan tes setelah tindakan yang dilakukan setiap akhir siklus untuk mengetahui hasil belajar setelah pelaksanaan tindakan.

Teknik analisis data yang digunakan pada penelitian ini adalah analisis deskriptif. Pendekatan deskriptif ada dua macam, yaitu kuantitatif dan kualitatif. Penelitian ini menggunakan pendekatan kuantitatif untuk menganalisis data berupa hasil tes. Data kemudian disajikan dalam bentuk tabel dan grafik. Pendekatan kualitatif digunakan untuk menganalisis data berupa hasil observasi dan angket. Analisis data yang digunakan akan dijelaskan sebagai berikut: 1) Data hasil tes. Hasil tes dianalisis untuk mengetahui hasil belajar matematika peserta didik setelah dilakukan pembelajaran menentukan pasangan bilangan dengan hasil kali tertentu dengan model bendera matematika Setelah diperoleh nilai tes peserta didik, langkah selanjutnya adalah menghitung rata-rata kelas dan persentase ketuntasan masing-masing siklus. Peserta didik dikatakan telah tuntas belajar jika memenuhi kriteria ketuntasan minimal yaitu 75 . Untuk menghitung nilai rata-rata kelas digunakan rumus sebagai berikut.

$$
\bar{X}=\frac{\sum X}{N}
$$


(Sudjana, 2010:125).

Keterangan:

$X \quad=$ Nilai rata-ra

$\sum \mathrm{x} \quad=$ Jumlah seluruh skor

$\mathrm{N} \quad=$ Banyaknya subjek.

Observasi ini untuk mengetahui pelaksanaan pembelajaran menggunakan model model bendera matematika baik untuk aktivitas guru selama proses pembelajaran maupun observasi untuk keterlibatan peserta didik. Pernyataan dalam pedoman observasi mempunyai dua alternatif jawaban, yaitu "ya" atau "tidak". Lembar observasi diisi dengan cara memberikan tanda centang (V). Setelah semua butir peryataan terisi semua maka langkah selanjutnya adalah memberi skor setiap butir. Jika "ya" maka butir tersebut diberi skor 1 dan jika "tidak" maka diberi skor 0. Kemudian dihitung persentasenya untuk mengetahui persentase keterlaksanaan pembelajaran dengan rumus sebagai berikut.

$$
\text { Persentase Skor }(\mathrm{P})=\frac{\text { skor yang diperoleh }}{\text { skor maksimal }} \times 100
$$

Pertanyaan pada lembar angket respon peserta didik mempunyai 2 alternatif jawaban, yaitu jawaban "ya" dan "tidak". Untuk respon positif jawaban "ya" diberi skor 1 sedang jawaban "tidak" diberi skor 0, sedang untuk respon negatif jawaban "ya" diberi skor 0, sedang jawaban "tidak" diberi skor 1. Skor angket yang diperoleh tiap peserta didik dihitung dengan menggunakan rumus:

$$
\mathrm{T}=\frac{\text { skor perolehan }}{\text { skor maksimal }} \times 100
$$


Kriteria pengkategorian yang digunakan adalah sebagai berikut.

Tabel 3. Kategori Angket Respon Siswa

\begin{tabular}{ll}
\hline Skor respon siswa & Kategori \\
\hline $80<\mathrm{T}<100$ & Sangat Baik \\
$60<\mathrm{T}<80$ & Baik \\
$40<\mathrm{T}<60$ & Cukup Baik \\
$20<\mathrm{T}<40$ & Kurang Baik \\
$0<\mathrm{T}<20$ & Sangat Kurang \\
\hline
\end{tabular}

Sumber dari

Widoyoko (2012:115)

Cara menghitung persentase respon peserta didik dalam tiap kategori adalah sebagai berikut.

$$
\text { Persentase }=\frac{\text { jumlah siswa dalam kategori }}{\text { jumlah seluruh siswa }} \times 100 \%
$$

Persentase yang didapat kemudian digunakan membuat kesimpulan mengenai respon peserta didik terhadap pembelajaran menggunakan "Metode Diskusi Berbantu Media Visual".

\section{HASIL DAN PEMBAHASAN}

\section{Hasil Pra Penelitian}

Pra penelitian berdasarkan analisis hasil pembelajaran selama ini ddiperoleh kesimpulan sebagai berikut: (1) Guru mengajarkan mater hanya menggunakan metode ceramah, (2) proses pembelajaran belum mendapatkan hasil sesuai KKM, dan (3) peserta didik kurang tertarik, karena materi abstrak.

Berdasarkan hasil tersebut peneliti menyusun rencana penelitian tindakan untuk memperbaiki pembelajaran. Hasil penyusunan tersebut adalah sebagai berikut:(1) Tersusunnya jadwal pelaksanaan tindakan siklus I. (2) Tersusunnya Rencana Pelaksanaan Pembelajaran (RPP) tentang materi yang diajarkan dan digunakan dalam tindakan. (3) Tersedianya media atau alat peraga yang akan digunakan dalam pembelajaran berupa media visual kemudian siswa mendiskusikannya. (4)Tersusunnya Lembar Kegiatan Peserta Didik (LKPD) yang digunakan dalam pembelajaran. (5) Tersusunnya kisi-kisi soal tes setelah tindakan 
siklus I dan lembar soal tes setelah tindakan siklus 1. (6) Tersusunnya angket respon siswa yang diberikan pada akhir siklus I. (7) Tersusunnya lembar observasi yang digunakan untuk mengetahui secara langsung pelaksanaan pembelajaran.

Untuk mengetahui kemampuan awal siswa dilakukan tes. Menurut Suharsimi Arikunto (2006: 150), tes merupakan serentetan pertanyaan atau latihan serta alat lain yang digunakan untuk mengukur ketrampilan, pengetahuan, intelegensi, kemampuan atau bakat yang dimiliki oleh individu atau kelompok. Dalam penelitian ini bentuk tes yang digunakan adalah tipe soal uraian. Bentuk uraian dipilih karena dipandang dapat memberikan indikasi yang baik untuk mengukur sejauh mana pemahaman siswa terhadap materi pelajaran yang didapatkan

Hasil analisis tes menunjukkan bahwa nilai rata-rata peserta didik kelas II SDN Wiladeg masih rendah yaitu 67,07, dan baru 18 dari 31 peserta didik yang mencapai KKM yang ditetapkan yaitu 70 atau sebesar $44 \%$ yang mencapai ketuntasan, seperti yang terlihat pada tabel 1 berikut:

Tabel 1 Perolehan Nilai Tes awal

\begin{tabular}{ll}
\hline Keterangan & Nilai \\
\hline Nilai tertinggi & 85 \\
Nilai terendah & 45 \\
Rata-rata nilai & 67,07 \\
Persentase siswa belajar tuntas & 44 \\
\hline
\end{tabular}

Berdasarkan hasil tersebut peneliti melaksanakan tindakan penelitian menggunakan metode yang berbeda .Dari metode ceramah berganti dengan metode diskusi berbantu visual.

\section{Hasil Pelaksanaan Penelitian}

Hasil Penelitian Tindakan Siklus 1

Berdasarkan catatan selama penelitian untuk siklus 1, guru mengawali kegiatan dengan memotivasi siswa dan memberikan cerita kegiatan sehari-hari dan menjelaskan tujuan dari pembelajaran dan kegiatan yang harus dilakukan. 
Siswa tampak antusias dalam pembelajaran. Beberapa siswa mengajukan soal sehingga waktu yang dialokasikan untuk menjelaskan bertambah. Pertemuan kedua soal yang dipraktekkan bersama dibatasi supaya waktu yang digunakan efisien.

Kegiatan dilanjutkan mengerjakan LKPD dalam kelompok. Ketika peserta didik mengerjakan soal dalam LKPD guru berkeliling untuk memberikan bimbingan. Soal selesai dikerjakan dilanjutkan presentasi kelompok. Akhir penelitian dilakukan evaluasi.

\section{Lembar Observasi Check-list}

Hasil pengamatan yang diperoleh dari isian lembar observasi pada kegiatan guru untuk siklus 1 terlihat pada tabel sebagai berikut

Tabel 2 Persentase Hasil Pengamatan Aktivitas Guru

\begin{tabular}{|c|c|c|c|}
\hline Obse & ver 1 & Obser & ver 2 \\
\hline Skor & Persentase & Skor & Persentase \\
\hline 18 & $81,82 \%$ & 18 & $81,82 \%$ \\
\hline
\end{tabular}

Pertemuan siklus 1 , dari 22 indikator yang diamati ada 4 indikator yang belum terlaksana. Diantaranya indikator 13 tentang guru membimbing siswa menarik kesimpulan, indikator 18 tentang guru melaksanakan pembelajaran sesuai dengan alokasi waktu yang direncanakan dan indikator 19 tentang guru melakukan refleksi atau merangkum dengan melibatkan siswa serta indikator 20 tentang guru melaksanakan tindak lanjut dengan memberikan arahan atau kegiatan atau tugas sebagai bagian remidi/pengayaan,sehingga skor rata-rata presentasi baru mencapai $81,82 \%$

Hasil Pengamatan Aktivitas Siswa

Hasil pengamatan aktivitas siswa dapat dilihat pada tabel berikut

Tabel 3 Hasil Pengamatan Aktivitas Peserta Didik

Siklus I 


\begin{tabular}{llll}
\hline \multicolumn{2}{l}{ Observer 1 } & \multicolumn{2}{l}{ Observer2 } \\
\hline Skor & Persentase & Skor & Persentase \\
\hline 7 & $77,78 \%$ & 7 & $77,78 \%$
\end{tabular}

Hasil pengamatan aktivitas peserta didik pada siklus I indikator yang diamati 9 indikator.Dari 9 indikator ada 2 indikator yang belum tercapai secara maksimal yaitu indikator kelima tentang sebanyak $80 \%$ peserta didik saling membantu antara anggota dalam kelompok belum muncul, yang terlihat baru $60 \%$ peserta didik saling membantu dalam kelompok.Juga indikator ke delapan tentang sebanyak $80 \%$ siswa mencatat rangkuman/kesimpulan pembelajaran baru ada 70 $\%$ peserta didik yang merangkum hasil pembelajaran.

\section{Hasil Tes Prestasi}

Hasil tes setelah tindakan siklus 1 nilai rata-rata peserta didik mencapai 67,75 sedangkan persentase ketuntasan peserta didik mencapai KKM $50 \%$. Nilai tertinggi 85 dan terendah 50 seperti terlihat dalam tabel 4

Tabel 4 Nilai Tes sesudah Tindakan Siklus 1

\begin{tabular}{ll}
\hline Keterangan & Nilai \\
\hline Nilai tertinggi & 90 \\
Nilai Terendah & 60 \\
Rata-rata nilai & 73,09 \\
Persentase siswa belajar Tuntas & $73 \%$ \\
\hline
\end{tabular}

Hasil Angket Tertutup Respon Peserta didik

Untuk mengetahui respon peserta didik sesudah pembelajaran siklus 1 berakhir, peserta didik diminta mengisi angket respon peserta didik. Rangkuman hasil dari angket pada siklus 1 seperti terlihat pada tabel berikut.

Tabel 5 Angket Tertutup Respon Peserta didik

\begin{tabular}{llll}
\hline No & Skor angket & Jumlah siswa & Kriteria skor \\
\hline 1 & 70 & 2 & Baik \\
2 & 80 & 2 & Sangat Baik \\
3 & 85 & 3 & Sangat Baik \\
4 & 90 & 4 & Sangat Baik \\
5 & 95 & 4 & Sangat Baik
\end{tabular}




\begin{tabular}{llll}
6 & 100 & 5 & Sangat Baik \\
Jumlah & 20 & \\
\hline
\end{tabular}

Berdasarkan tabel di atas ada 2 peserta didik yang mendapat skor 70 dalam kategori baik. Sedangkan peserta didik lainnya mendapat skor antara 80 - 100 dalam kategori sangat baik.

\section{Hasil Refleksi}

Refleksi dilakukan oleh peneliti bersama dengan kolaborator setelah pembelajaran siklus 1 berakhir. Hasil rata-rata tes setelah tindakan siklus 1 mencapai 73,09 hal ini menunjukkan peningkatan dari hasil tes sebelum tindakan yang hanya mencapai nilai rata-rata 67,07 , tetapi belum mencapai kriteria keberhasilan yang ditetapkan dalam KKM yaitu 75 .

Persentase peserta didik yang mencapai ketuntasan belajar adalah 22 dari 31 peserta didik atau mencapai $70 \%$ pada tes setelah tindakan 1, sudah mengalami peningkatan dari tes sebelum tindakan yang hanya mencapai $44 \%$. Namun belum memenuhi kriteria keberhasilan yang ditetapkan yaitu $75 \%$ peserta didik mencapai KKM yaitu 75. hasil tersebut seperti terlihat pada tabel 9. Guru dan murid bersama-sama berusaha agar KKM tercapai. Murid harus lebih rajin belajar dan guru melakukan inovasi pembelajaran. Jika keduanya bersinergi niscaya ketercapaian KKM bukan hal yang sulit untuk tercapai.

Tabel 6 Perbandingan Nilai Sebelum Tindakan dan setelah Tindakan Siklus I

\begin{tabular}{lll}
\hline Keterangan & $\begin{array}{l}\text { Sebelum } \\
\text { Tindakan }\end{array}$ & $\begin{array}{l}\text { Setelah } \\
\text { tindakan }\end{array}$ \\
\hline Nilai tertinggi & 85 & 90 \\
Nilai terendah & 45 & 60 \\
$\begin{array}{l}\text { Rata-rata nilai } \\
\begin{array}{l}\text { Persentase peserta } \\
\text { belajar tuntas }\end{array}\end{array}$ & 67,07 & 73,09 \\
\hline
\end{tabular}


Hasil skor angket peserta didik menunjukkan 3 peserta didik dalam kategori baik dan 28 peserta didik memberikan respon sangat baik. Dua anak yang belum tertarik karena anak tersebut memang pendiam.

Hasil penelitian siklus 1, secara umum pelaksanaan pembelajaran menggunakan metode diskusi berbantu media visual dapat berjalan baik.

Berikut beberapa permasalahan yang muncul pada pelaksanaan siklus 1: a) Pengaturan waktu kurang tepat. b) Guru belum melakukan refleksi atau merangkum dengan melibatkan siswa. c) Pembagian kelompok belum merata antara yang berkemampuan rendah dan tinggi. d) Peserta didik belum mencapai KKM sesuai target.Semua masalah yang muncul pada pelaksanaan siklus 1 pada siklus 2 direkomendasikan perlakuan khusus supaya dapat menyempurnakan tindakan.

Hasil Penelitian Tindakan Siklus 2

Berdasarkan catatan lapangan pada siklus 1 tahap perencanaan mendapatkan hasil sebagai berikut: 1) Tersusun RPP siklus dan 2)Tersusun LKPD siklus 2. Data hasil observasi aktivitas guru siklus 2 sebagai berikut:

Tabel 7 Observasi Aktivitas Guru Siklus 2

Siklus II

\begin{tabular}{llll}
\hline \multicolumn{2}{l}{ Observer 1 } & \multicolumn{2}{l}{ Observer 2 } \\
\hline Skor & Persentase & Skor & Persentase \\
\hline 21 & $95,45 \%$ & 21 & $95,45 \%$
\end{tabular}

Menurut data di atas guru sudah senang menggunakan model bendera matematika. Terbukti aktivitasnya sudah dinilai oleh observer sebesar 95,45\%. Data hasil observasi aktivitas peserta didik siklus 2 sebagai berikut:

Tabel 8 Observasi Aktivitas Peserta Didik Siklus 2

\begin{tabular}{llll}
\multicolumn{2}{l}{ Siklus } & II \\
\hline \multicolumn{2}{l}{ Observer 1 } & \multicolumn{2}{l}{ Observer 2 } \\
\hline Skor & Persentase & Skor & Persentase \\
\hline 9 & $100 \%$ & 9 & $100 \%$
\end{tabular}


Berdasarkan tabel 8 tersebut aktivitas peserta didik sudah focus pada pembelajaran. Hal ini dibuktikan dengan semua unsur dalam lembar observasi mendapat skor 9. Hasil tes prestasi siklus 2 tertera pada tabel berikut:

Tabel 9 Observasi Tes Prestasi Peserta Didik Siklus 2

\begin{tabular}{ll}
\hline Keterangan & Nilai \\
\hline Nilai tertinggi & 100 \\
Nilai terendah & 70 \\
Rata-rata nilai & 84,25 \\
Persentase siswa belajar tuntas & $100 \%$ \\
\hline
\end{tabular}

Hasil dari angket peserta didik siklus 2 terlihat pada tabel berikut:

Tabel 10 Observasi Angket Tertutup Peserta Didik Siklus 2

\begin{tabular}{lll}
\hline Skor angket & Jumlah Peserta Didik & Kategori Skor \\
\hline 85 & 3 & Sangat Baik \\
90 & 5 & Sangat Baik \\
95 & 5 & Sangat Baik \\
100 & 7 & Sangat Baik \\
\hline
\end{tabular}

Hasil tes akhir setelah tindakan pada siklus 2 menunjukkan peningkatan, dapat diihat di tabel berikut :

Tabel 11 Perbandingan Perolehan Nilai Setelah Siklus 1 dan 2

\begin{tabular}{lll}
\hline \multirow{2}{*}{ Keterangan } & Nilai & \\
\cline { 2 - 3 } & Siklus 1 & Siklus 2 \\
\hline Nilai tertinggi & 90 & 100 \\
Nilai terendah & 60 & 75 \\
Rata-rata nilai & 73,09 & 83,79 \\
$\begin{array}{l}\text { Persentase siswa } \\
\text { tuntas }\end{array}$ & & $100 \%$ \\
\hline
\end{tabular}

Begitu juga hasil angket respon peserta didik mengalami peningkatan seperti terlihat pada siklus 1 yang memberikan respon sangat baik mencapi 77,78 
$\%$ meningkat menjadi $100 \%$ pada siklus 2 Keberhasilan pada siklus 2 signifikan dengan kriteria penelitian sehingga peneliti memutuskan untuk menghentikan penelitian tersebut.Hasil dari pengamatan siklus 1 dan siklus 2 peserta didik antusias dan senang menggunakan model alat peraga potongan kertas. Hasil pengamatan peneliti sebagai berikut:

Tabel 12 Perbandingan Perolehan Nilai angket Respon Peserta Didik Setelah Siklus 1 dan 2

\begin{tabular}{ll|ll}
\hline Siklus I & & Siklus II & \\
\hline Skor & Persentase & Skor & Persentase \\
\hline 19 & $86,3 \%$ & 21 & $100 \%$ \\
\hline
\end{tabular}

Setelah tindakan siklus 2 berakhir siswa mengisi angket, hasilnya adalah sebagai berikut

Tabel 13 Hasil Angket Respon Peserta Didik Setelah Siklus 1 dan 2

\begin{tabular}{|c|c|c|c|}
\hline No & Skor Angket & Jumlah siswa & Kriteria Skor \\
\hline 1 & 85 & 3 & Sangat Baik \\
\hline 2 & 90 & 5 & Sangat Baik \\
\hline 3 & 95 & 5 & Sangat Baik \\
\hline 4 & 100 & 7 & Sangat Baik \\
\hline \multicolumn{2}{|c|}{ Jumlah } & 20 & \\
\hline
\end{tabular}

Berikut hasil tes tertulis antara sebelum dan sesudah tindakan.

Tabel 14 Hasil Tes Peserta Didik Sebelum dan Setelah Siklus 1 dan 2

\begin{tabular}{lll}
\hline Keterangan & Sebelum Tindakan & Setelah Tindakan \\
\hline Nilai Tertinggi & 100 & 100 \\
Nilai Terendah & 40 & 75 \\
Rata-rata Nilai & 72,86 & 91,79 \\
Presentase Belajar Tuntas & $53,57 \%$ & $100 \%$ \\
\hline
\end{tabular}

Hasil penelitian menjawab pertanyaan penelitian, sehingga memenuhi semua kriteria keberhasilan dari penelitian. Berdasarkan deskripsi pelaksanaan tindakan siklus 1 dan siklus 2 yang telah menggunakan metode diskusi berbantu 
media visual hasilnya meningkat. Hasil tes sebelum tindakan, tes setelah tindakan siklus 1 dan tindakan siklus 2 menunjukkan peningkatan tersebut. Namun untuk lebih jelasnya dibahas lebih lanjut sebagai berikut. 1) Meningkatnya Nilai RataRata Peserta Didik Kelas II. Secara umum nilai rata-rata kelas mengalami peningkatan. Peningkatan nilai rata-rata kelas dapat dilihat pada gambar berikut:

Gambar 1 Peningkatan Nilai Rata-Rata

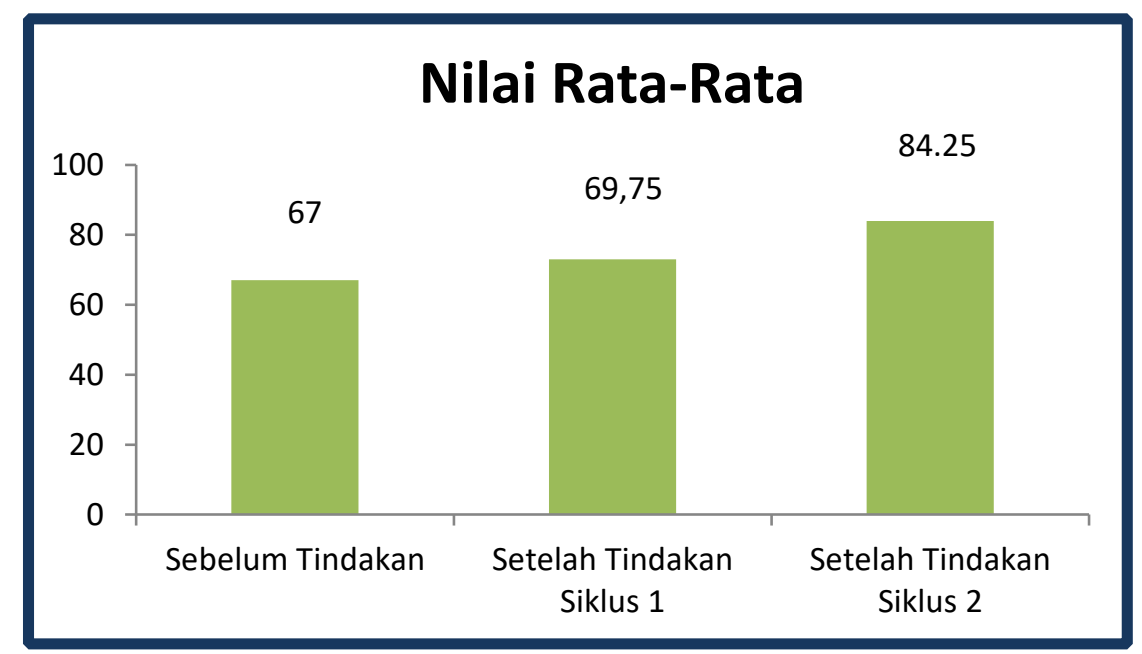

Gambar 1 terlihat adanya peningkatan nilai rata-rata tes sebelum tindakan mencapai 65,75, tes setelah tindakan siklus 1 meningkat menjadi 69,75, dan setelah tindakan siklus 2 mencapai rata-rata 84,25.

Pembagian kelompok siklus 1 masih terlalu besar sehingga kesempatan peserta didik untuk mencoba media masih terbatas dan peserta didik masih terkonsentrasi dengan soal yang menjadi bagiannya sehingga belum dapat belajar secara maksimal. Siklus 2 materi menentukan pasangan bilangan dengan hasil kali tertentu belum mendapatkan hasil yang maksimal. Hal ini dibuktikan pada akhir pembelajaran beberapa siswa masih salah dalam menemukan jawaban dengan benar.

Berdasarkan pengamatan siklus 1 guru belum membimbing siswa menarik kesimpulan. Kerja sama dalam kelompok belum optimal, sehingga tutor sebaya belum dapat berjalan sebagaimana mestinya. Siklus 2 kerja sama dalam kelompok meningkat: 1) Meningkatnya Persentase Siswa yang mencapai KKM. Persentase siswa yang mencapai kriteria ketuntasan minimal dari siklus 1 dan siklus 2 mengalami peningkatan. Hal demikian membuktikan model bendera matematika 
efektif digunakan dalam pembelajaran perkalian bilangan berpasangan untuk ditentukan hasilnya dengan benar dan riil.

Gambar 2 Persentase Capaian KKM

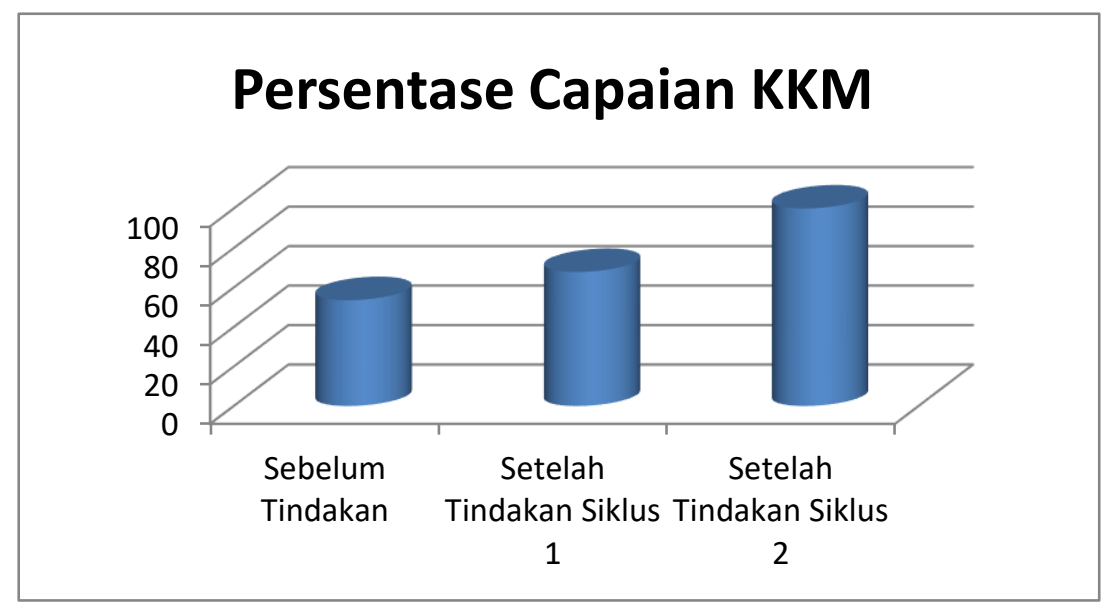

Hal ini sejalan dengan penelitian yang dilakukan oleh Mukti Trima, (2012) yang menyatakan bahwa alat peraga meningkatkan keterampilan operasi hitung bilangan bulat dalam hal kecepatan dan ketepatannya. 1) Respon Peserta Didik. Respon peserta didik dari siklus 1 dan siklus 2 dalam kategori sangat baik. Anak menjadi aktif melakukan penghitungan pasangan bilangan untuk dikalikan. Hal demikian sesuai dengan yang dikemukakan oleh Felmand (2012: 214) di mana siswa kelas II dalam tahap operasional konkret (Piaget)

Namun pemahaman konsep matematika terkadang menjadi sulit dimengerti oleh siswa khususnya SD, karena pada dasarnya konsep matematika merupakan hal yang abstrak. Sementara itu proses berfikir siswa SD masih dalam tahapan operasional konkret. Hal ini yang menjadi terputusnya proses berfikir siswa. Kurangnya inovasi dan kreasi guru dalam membelajarkan matematika menjadi tambahan persoalan bagi siswa untuk memahami konsep matematika itu senndiri. Tidak jarang konsep matematika yang seharusnya dipahami hanya dihafal oleh siswa karena guru mengajarkan konsep secara abstrak.

Suatu proses pembelajaran dapat dikatakan baik apabila melibatkan proses berfikir. Dengan demikian siswa menggunakan kemampuan kognitif/ intelektualnya. Dalam belajar matematika, siswa perlu menggunakan kemampuan 
kognitifnya tersebut untuk belajar mengenai konsep-konsep dan struktur-struktur matematika serta mencari hubungan antara keduanya. Sehingga dalam proses belajar sebaiknya anak usia SD diberi kesempatan untuk memanipulasi bendabenda atau alat peraga dan dapat diotak atik sendiri, berkomunikasi dengan orang lain sehingga terciptalah suatu interaksi. Didalam interaksi inilah terjadi proses saling mempengaruhi

Abstraknya materi pelajaran hendaknya memotivasi guru untuk melakukan inovasi. Guru yang aktif dan kreatif melakukan inovasi pasti disenangi oleh peserta didik.Hal ini disebabkan pembelajaran menjadi menarik dan menyenangkan untuk diikuti dan dipelajari.

\section{Keterlaksanaan Pembelajaran}

Pembelajaran selama proses penelitian selama 3 hari. Setiap pertemuan selama 2 jam pelajaran atau 70 menit. Saat penelitian terbagi ke dalam 2 siklus. Siklus 2 persentase ketercapaian mencapai 88,9\% dari 9 indikator yang diamati. Penggunaan media juga mempengaruhi untuk menyelesaikan soal. Hal demikian sesuai pendapat Suparno (2001: 69) yang menyatakan operasi logis itu bersifat reversibel, artinya dapat dimengerti dalam dua arah.

\section{SIMPULAN}

Berdasarkan hasil penelitian dapat disimpulkan bahwa pelaksanaan pembelajaran menggunakan metode diskusi berbantuan media audio visual di SD Negeri Wiladeg pada materi Kenampakan Permukaan Bumi dapat meningkatkan prestasi belajar siswa kelas V dari rata-rata sebesar 67,07 sebelum tindakan dengan persentase ketuntasan 44\% menjadi 73,09 dengan ketuntasan sebesar 75,86\% pada siklus I. Dalam siklus II pada materi Memelihara dan Melestarikan Lingkungan Alam rata-rata prestasi belajar siswa dapat meningkat menjadi 84 dengan ketuntasan belajar sebesar 86,20\%. Dari hasil observasi kegiatan guru dan wawancara pada siklus II diperoleh data bahwa metode diskusi berbantuan media audio visual ini menjadikan pembelajaran lebih menarik, membuat siswa lebih antusias dalam pembelajaran, dan menambah pengetahuan serta pengalaman guru. 


\section{DAFTAR PUSTAKA}

Cecep Kustandi dan Bambang Sutjipto. 2011. Media Pengajaran Manual dan Digital. Jakarta : Ghalia Indonesia.

Daryanto. 2013. Strategi dan Tahapan Mengajar: Bekal Keterampilan Dasar bagi . Bandung : Yrama Widya

Iskadar. 2011. Penelitian Tindakan Kelas. Jakarta : Gaung Persada Kasihani Kasbolah E.S dan I Wayan Sukarnyana. 2006. Penelitian Tindakan Kelas Untuk Guru. Malang : Universitas Negeri Malang Mitsbah El Noor. 2011. Peningkatan Prestasi Belajar IPA dengan Menggunakan Media Gambar Audio Visual pada Siswa Kelas III SD Negeri Tanjungtirto II Berbah Sleman Tahun Ajaran 2010/2011. Skripsi

Winkel, WS 1987. Bimbingan dan Konseling di Institusi Pendidikan. Jakarta: Gramedia 